\title{
FACTORS INFLUENCING CONSUMERS BUYING FOOD AT HALAL RESTAURANT PEKANBARU CITY
}

\author{
Utin Munawaroh¹, Mahendra Romus², Hasbullah ${ }^{3}$ \\ 1Fakultas Pascasarjana UIN Sultan Syarif Kasim Riau, Pekanbaru, Indonesia. \\ 2Fakultas Ekonomi dan Ilmu Sosial UIN Sultan Syarif Kasim Riau, Pekanbaru, Indonesia. \\ ${ }^{3}$ Fakultas Ushuluddin, UIN Sultan Syarif Kasim Riau, Pekanbaru, Indonesia. \\ e-mail: munawarah1995@gmail.com
}

\begin{abstract}
Abstrak: Restoran sebagai salah satu penyedia makanan dan minuman menjadi salah satu sarana bagi konsumen dalam memenuhi kebutuhannya dimana salah satunya adalah konsumen Muslim. Bagi konsumen Muslim, perintah mengkonsumsi makanan dan minuman halal menjadi dasar dalam memenuhi setiap kebutuhan. Tujuan penelitian ini adalah untuk mengetahui faktorfaktor apa saja yang mempengaruhi konsumen membeli dengan menggunakan metode deskriptif kuantitatif. Teknik pengumpulan data menggunakan kuesioner dan dokumentasi. Sampel diambil sebanyak 100 responden menggunakan teknik accidental sampling kemudian diperoleh kesimpulan berdasarkan persamaan regresi linier berganda untuk pengaruh faktor eksternal dan faktor internal terhadap keputusan membeli adalah $\mathrm{Y}=-42.299+1.903 \mathrm{X} 1+$ 1.091X2. Faktor eksternal dengan skor rata-rata 80.9 masuk dalam kategori "baik" dan berpengaruh terhadap keputusan membeli berdasarkan thitung (7.898) > ttabel (1.984) dengan uji dua pihak dan derajat bebas (df) $=98 ; a=0,05$. Faktor internal dengan skor rerata 82.3 masuk dalam kategori "baik" dan berpengaruh terhadap keputusan membeli berdasarkan thitung (15.267) > ttabel (1.984). Sedangkan secara simultan faktor eksternal dan faktor internal secara bersama-sama berpengaruh terhadap keputusan membeli karena nilai Fhitung (136.839) > Ftabel (3.090). Dan faktor yang paling dominan mempengaruhi keputusan membeli adalah faktor internal (X2) sebesar 15.267.
\end{abstract}

Kata Kunci: Faktor Eksternal, Faktor Internal, Keputusan Membeli 


\section{PENDAHULUAN}

Sebagai masyarakat kota madani yang agamis dan berperadaban sudah seharusnya dalam setiap pemenuhan kebutuhan terutama makanan dan minuman haruslah sesuai dengan tuntunan agama (Islam). Perintah mengkonsumsi makanan dan minuman halal telah dijelaskan di dalam Al-Qur'an dan menjadi dasar bagi setiap Muslim untuk memperhatikan dan mengkonsumsi makanan dan minuman yang halal saja.

Urgensi halal menjadi mutlak terutama bagi konsumen Muslim dalam memilih, membeli dan mengkonsumsi makanan. Sedemikiannya dalam menentukan kedudukan halal dan haram hingga sebagian ulama menyatakan "Hukum Islam (fikih) adalah pengetahuan tentang halal dan haram". Hal tersebut secara jelas dinyatakan dalam Surah alBaqarah ayat 168 yang berbunyi:

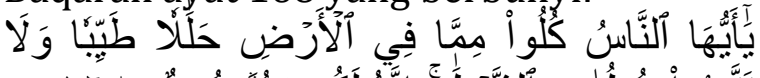

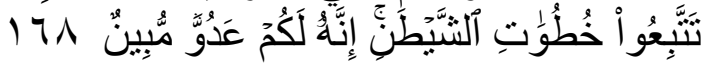
Artinya: "Hai sekalian manusia, makanlah yang halal lagi baik dari apa yang terdapat di bumi. Janganlah mengikuti langkah-langkah setan karena setan adalah musuh nyata bagimu".

Ayat di atas memberikan perintah yang jelas kepada seluruh umat manusia untuk memilih makanan dengan kriteria halal dan tayyib. Kehalalan makanan dapat dilihat dari empat aspek, yaitu: pertama, halal dalam cara memperolehnya. Kedua, halal zat/bahan dasarnya. Ketiga, halal dalam proses pengolahannya. Keempat, halal dalam proses pengemasannya. Sedangkan kriteria tayyib menurut Abu Bakr Ibn al'Arabî yaitu sesuatu yang layak bagi tubuh dan dirasakan lezatnya serta sesuatu yang dihalalkan oleh Allah SWT (Ali, 2016).

Di Negara Indonesia, dalam hal menjamin kehalalan suatu produk dibentuk suatu lembaga yang kompeten yaitu Majelis Ulama Indonesia yang berperan melalui LPPOM MUI (Lembaga Pengkajian Pangan Obat-obatan dan Kosmetika Majelis Ulama Indonesia) di mana tugasnya adalah untuk mengawasi produk yang beredar di masyarakat, dengan cara mengeluarkan sertifikat halal. Selanjutnya produk yang telah memiliki sertifikat halal tersebut dapat mencantumkan label halal pada produknya. Di samping itu, pemerintah juga telah memfasilitasi Muslim dengan adanya UU No. 08 Tahun 1999 tentang Perlindungan Konsumen dan UU Nomor 33 Tahun 2014 tentang JPH (Jaminan Produk Halal) (LPPOM MUI, 2015).

Adanya peraturan pemerintah dan undang-undang produk halal menunjukkan kepedulian pemerintah untuk memberikan jaminan keamanan dan kehalalan pangan bagi masyarakat khususnya umat Islam. Namun kesadaran muslim terhadap produk halal belum diketahui secara pasti.

Restoran dalam Peraturan Daerah Kota Pekanbaru Nomor 6 Tahun 2011 Tentang Pajak Restoran merupakan salah satu penyedia kebutuhan makanan dan/atau minuman yang dipungut bayaran yaitu mencakup rumah makan, kafetaria, bar dan sejenisnya memiliki perkembangan yang sangat pesat dan memiliki banyak penikmat diantaranya yaitu dari kalangan konsumen muslim.

Provinsi Riau khususnya Kota Pekanbaru saat ini menyuguhkan berbagai macam usaha kuliner yang sangat menjanjikan, banyak ragam jenis makanan dan minuman yang bermunculan, selain itu bidang usaha kuliner seperti restoran, rumah makan dan cafe bermunculan. Hal ini sangat baik bagi perkembangan industri pariwisata sebab kebutuhan akan makanan dan 
minuman mutlak diperlukan bagi wisatawan yang berkunjung.

Pertumbuhan restoran di Kota Pekanbaru dilihat dari data restoran yang telah memiliki izin buka usaha sebanyak 399 restoran (Pejabat Pengelola Informasi dan Dokumentasi, 2019). Pertumbuhan restoran yang sangat pesat ini tentunya memiliki dampak positif bagi konsumen karena dengan semakin banyaknya restoran maka semakin banyak pilihan bagi konsumen.

\begin{tabular}{lllr}
\multicolumn{1}{c}{ Namun } & \multicolumn{2}{c}{ yang } & menjadi \\
kekhawatiran & yaitu & baru & beberapa \\
restoran & saja & yang & telah \\
mengantongi/memiliki & sertifikat & halal.
\end{tabular}
Restoran yang memiliki sertifikat halal berdasarkan data LPPOM MUI yaitu sebanyak 14 restoran. Artinya masih banyak restoran yang belum memiliki sertifikat halal. Sebagai konsumen Muslim dalam memilih untuk membeli makanan di restoran mengharuskan konsumen menjadi cerdas dan selektif dalam menentukan pilihan terkait memenuhi kebutuhan hidupnya.

\section{TINJAUAN PUSTAKA \\ Perilaku Konsumen}

Perilaku konsumen merupakan studi yang mengkaji bagaimana individu membuat keputusan membelanjakan sumber dayanya yang tersedia dan dimiliki (waktu, uang, usaha) untuk mendapatkan barang atau jasa yang nantinya akan dikonsumsi (Suryani, 2008:20).

Perilaku konsumen merupakan tindakan-tindakan yang dilakukan oleh individu, kelompok atau organisasi yang berhubungan dengan proses pengambilan keputusan dalam mendapatkan, menggunakan barang-barang atau jasa ekonomis yang dapat dipengaruhi lingkungan (Mangkunegara, 2005:4).

\section{Faktor yang Mempengaruhi Perilaku Konsumen}

Perilaku konsumen sangat dipengaruhi oleh keadaan dan situasi lapisan masyarakat, dimana ia dilahirkan dan berkembang. Ini berarti konsumen berasal dari lapisan masyarakat atau lingkungan yang berbeda akan mempunyai penilaian, kebutuhan, pendapat, sikap dan selera yang berbedabeda sehingga pengambilan keputusan dalam tahap pembelian akan dipengaruhi oleh beberapa faktor. Faktor-faktor yang mempengaruhi perilaku konsumen dapat dilihat pada tabel berikut ini:

\section{Tabel 1.}

Faktor-faktor yang mempengaruhi perilaku konsumen

\begin{tabular}{|c|c|}
\hline Faktor Eksternal & Faktor Internal \\
\hline Kebudayaan & Motivasi \\
\hline Kelas Sosial & Persepsi \\
\hline $\begin{array}{c}\text { Kelompok } \\
\text { Referensi }\end{array}$ & Kepribadian \\
\hline & $\begin{array}{c}\text { Kepercayaan dan } \\
\text { sikap }\end{array}$ \\
\hline
\end{tabular}

Sumber: Setiadi, 2003

Faktor eksternal adalah faktor yang terdapat diluar diri individu konsumen. Diantaranya:

Kebudayaan merupakan penentu keinginan dan perilaku yang paling dasar. Kebudayaan ini memainkan peranan penting dalam pembentukan sikap konsumen dan merupakan petunjuk penting mengenai nilai-nilai yang akan dianut oleh seorang konsumen (Setiadi, 2010:11).

Kelas sosial adalah pembagian individu di dalam masyarakat yang terdiri dari individu-individu yang berbagi nilai, minat dan perilaku yang sama. Ukuranukuran yang biasa digunakan untuk menggolongkan masyarakat adalah pendapatan, pendidikan, pekerjaan kekayaan dan sebagainya. Kelas sosial dapat menunjukkan preferensi produk 
dan pemilihan merek yang berbeda-beda dalam berbagai kategori produk (Setiadi, 2003:11).

Kelompok referensi merupakan kelompok yang menjadi ukuran seseorang unutk membentuk kepribadian perilakunya. Pengaruh kelompok referensi merupakan bagian dari proses pembelajaran lingkungan. Anggotaanggota kelompok sangat berperan dalam proses sosialisasi konsumen yaitu bagaimana seseorang menjadi konsumen. Kelompok referensi memberikan manfaat terhadap pemahaman mengenai pengaruh terhadap sikap, perilaku dan kepercayaan konsumsi individu (Sunyoto, 2012:258).

Selanjutnya faktor internal adalah faktor yang berasal dari dalam diri konsumen itu sendiri. Diantaranya:

Motivasi merupakan keadaan di dalam pribadi seseorang yang mendorong keinginan individu untuk melakukan kegiatan-kegiatan guna mencapai suatu tujuan. Dengan adanya motivasi pada diri seseorang akan menunjukkan suatu perilaku yang diarahkan pada suatu tujuan untuk mencapai sasaran kepuasan (Setiadi, 2003:25).

$$
\text { Persepsi didefinisikan sebagai }
$$
proses di mana seseorang memilih, mengorganisasikan, mengartikan masukan informasi untuk menciptakan suatu gambaran yang berarti dari dunia ini. Persepsi dapat melibatkan penafsiran seseorang atas suatu kejadian berdasarkan pengalaman masa lalunya (Sunyoto, 2012:265).

Kepribadian merupakan pola sifat individu yang dapat menentukan tanggapan untuk bertingkah laku yang mencangkup kebiasaan-kebiasaan, sikap dan ciri-ciri sifat dan watak yang khusus yang menentukan perbedaan tiap-tiap individu. Setiap orang mempunyai kepribadian yang berbeda yang akan mempengaruhi perilaku membeli (Setiadi, 2003:61-62).

Kepercayaan dan sikap. Kepercayaan merupakan pengetahuan mengenai suatu objek, atributnya dan manfaatnya. Sedangkan sikap adalah kecenderungan bertindak, berpersepsi, berpikir, dan merasa dalam menghadapi objek, ide, situasi atau nilai (Rakhmat, 2012:39).

\section{Keputusan Membeli}

Sebelum membeli suatu produk atau jasa, umumnya konsumen melakukan evaluasi untuk melakukan pemilihan produk atau jasa. Evaluasi dan pemilihan yang digunakan menghasilkan suatu keputusan. Pengambilan keputusan sendiri merupakan sebuah proses yang terdiri dari beberapa tahap, berikut gambar tahapan dari pengambilan keputusan (Setiadi, 2003:14).

Gambar 1.

\section{Tahapan pengambilan keputusan}

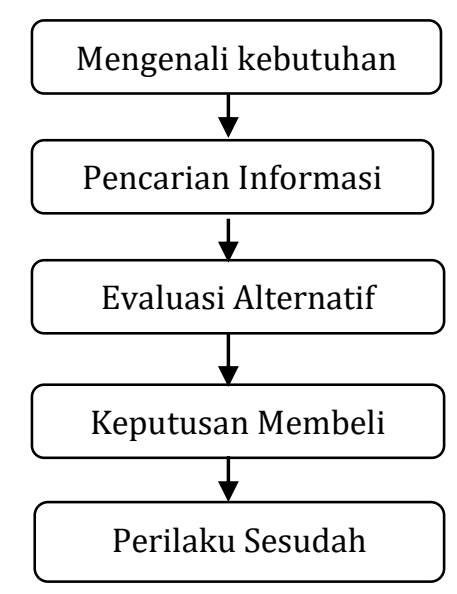

Keputusan pembelian merupakan suatu proses pengambilan keputusan akan pembelian yang mencakup penentuan apa yang dibeli atau tidak melakukan pembelian dan keputusan itu diperoleh dari kegiatan-kegiatan sebelumnya (Sofjan, 2004:141). 
Keputusan pembelian adalah tahap dimana pembeli telah menentukan pilihannya dan melakukan pembelian produk serta mengkonsumsinya. Hal ini berkaitan dalam usahanya memenuhi kebutuhan dengan tahap yang dilibatkan dalam mengevaluasi, memperoleh dan menggunakan produk (Suharno, 2010:96).

\section{METODE}

Penelitian ini menggunakan metode klasifikasi desain penelitian menurut Uma Sekaran, yaitu (Sekaran, 2006:165-173).

1. Tujuan studi untuk penelitian ini adalah pengujian hipotesis Dalam penelitian ini menjelaskan hubungan variabel $\mathrm{X} 1$ faktor Eksternal dan X2 faktor Internal terhadap Keputusan Konsumen Membeli Makanan di Restoran Halal.

2. Jenis Investigasi menggunakan studi korelasional dimana peneliti berminat untuk menemukan variabel penting yang berkaitan dengan masalah.

3. Tingkat intervensi yang digunakan adalah tingkat intervensi minimal yaitu dengan menggunakan cara penyebaran kuesioner.

4. Konteks Studi (Situasi studi) untuk penelitian ini adalah studi lapangan. Dalam penelitian ini dilakukan di Restoran Halal Kota Pekanbaru.

5. Unit analisis yang digunakan dalam penelitian ini adalah individu yaitu dengan melakukan penyebaran kuesioner secara langsung terhadap responden.

6. Horizon waktu untuk melakukan penelitian ini adalah crossselectional, sebuah studi dapat dilakukan dengan data yang hanya sekali dikumpulkan, mungkin selama periode harian, mingguan, atau bulanan dalam rangka menjawab pertanyaan penelitian. Dalam penelitian ini dilakukan pada bulan Mei 2019.

Populasi dalam penelitian ini adalah seluruh konsumen yang membeli makanan di restoran halal Kota Pekanbaru. Adapun jumlah restoran halal yang ada di Kota Pekanbaru yaitu sebanyak 14 restoran. Teknik pengambilan sampel menggunakan teknik accidental sampling. Populasi adalah tidak terbatas, jadi sebuah sampel sebanyak 100 orang yang diambil dari popoulasi berjumlah 5000 secara kasar mempunyai ketepatan estimasi yang sama dengan 100 sampel yang diambil dari 200 juta populasi. Jadi sampel dalam penelitian ini adalah 100 responden yang berasal dari konsumen restoran halal di Kota Pekanbaru (Cooper, 1996:221).

\section{HASIL DAN PEMBAHASAN}

Dari hasil analisis identitas responden diketahui bahwa sebagian besar responden adalah perempuan yaitu sebanyak 67 orang atau sebesar $67 \%$ yang mayoritasnya berstatus kawin sebanyak 66 orang atau sebesar $66 \%$ dengan mayoritas rentang usia 21-30 tahun sebanyak 53 orang atau sebesar $53 \%$ yang memiliki pendidikan mayoritas SMA sebanyak 54 orang atau sebesar $54 \%$ dengan pekerjaan konsumen mayoritas sebagai pegawai swasta sebanyak 34 orang atau $34 \%$ dan pendapatan konsumen mayoritas sebesar Rp. 1.000.000-Rp 2.000.000 sebanyak 45 orang atau $45 \%$. 


\section{Berdasarkan Hasil Analisis Pernyataan Responden}

Jika dilihat dari hasil analisis pernyataan pada kuesioner, hasil penelitian setiap variabel diperoleh kesimpulan sebagai berikut: Pada variabel faktor eksternal terdapat 3 indikator utama diantaranya, indikator kebudayaan, indikator kelas sosial dan indikator kelompok referensi.

1. Pada indikator kebudayaan diperoleh hasil total skor sebesar 430 menunjukkan bahwa sebagai masyarakat yang agamis dan berperadaban budaya melayu konsumen membeli makanan karena mengikuti tuntunan agama yaitu mengutamakan mengkonsumsi makanan halal di mana perintah mengkonsumsi makanan dan minuman halal dalam al-Qur'an menjadi dasar bagi setiap muslim untuk memperhatikan dan memilih untuk mengkonsumsi makanan dan minuman halal.

2. Pada indikator Kelas Sosial diperoleh hasil total skor sebesar 409 dapat disimpulkan bahwa konsumen setuju membeli makanan di Restoran halal karena harga yang relatif terjangkau bagi konsumen.

3. Pada indikator Kelompok Referensi diperoleh hasil total skor sebesar 411 menunjukkan bahwa konsumen dalam membeli makanan berdasarkan rekomendasi dan ajakan dari teman mapun keluarga.

Maka berdasarkan hasil total skor diketahui bahwa variabel yang berpengaruh terhadap keputusan membeli yaitu pada indikator Kebudayaan yang menunjukkan bahwa konsumen sebagai masyarakat yang agamis dan berperadaban budaya melayu sangat tegas dalam memilih dan membeli makanan karena mengikuti konsep yang sudah diajarkan.

Pada variabel faktor internal terdapat 4 indikator utama diantaranya, indikator motivasi, indikator persepsi dan indikator kepribadian serta indikator kepercayaan dan sikap.

1. Pada indikator Motivasi diperoleh hasil total skor sebesar 417 ini menunjukkan bahwa konsumen termotivasi membeli karena di restoran ini menyediakan makanan halal sehingga mereka tidak ragu untuk mengkonsumsinya.

2. Pada indikator Persepsi diperoleh hasil total skor sebesar 420 ini menunjukkan bahwa konsumen beranggapan restoran sudah terjamin kehalalannya dilihat dari adanya logo halal dari LPPOM-MUI sehingga konsumen merasa nyaman membeli makanan.

3. Pada indikator Kepribadian diperoleh hasil total skor sebesar 411 menunjukkan bahwa dalam membeli makanan konsumen menyesuaikan dengan selera yang dimiliki dan restoran yang diminati oleh banyak orang.

4. Pada indikator Kepercayaan diperoleh hasil toral skor sebesar 328 dan Sikap diperoleh hasil total skor tertinggi sebesar 430 ini menunjukkan bahwa tatanan masyarakat yang madani membentuk sikap konsumen dalam mengkonsumsi makanan dan kehalalan menjadi tolak ukur dalam membeli makanan. 
Maka berdasarkan hasil total skor diketahui bahwa variabel yang berpengaruh terhadap keputusan membeli yaitu pada indikator Sikap konsumen di mana ini menunjukkan bahwa kepercayaan konsumen terhadap suatu produk sangat mempengaruhi sikap dan keputusannya dalam membeli.

\section{Berdasarkan Hasil Analisis Data Menggunakan SPSS 22.0}

Jika dilihat dari hasil pengolahan data maka didapatkan hasil analisis data sebagai berikut:

Uji Validitas. Nilai $r$ table untuk penelitian ini adalah $\mathrm{N}=\mathrm{n}-2$ yaitu $\mathrm{N}=$ $100-2=98$ dan $r$ tabel yang diperoleh sebesar 0.202 mengacu kepada table $r$ (Korelasi Pearson) dengan taraf signifikan 5\%. Jika $r$ hitung lebih kecil dari $r$ table maka kuesioner tersebut dikatakan tidak valid sebagai instrument penelitian. Adapun hasil uji validitas dalam penelitian ini menunjukkan bahwa 99.98\% dari data rhitung lebih besar dibandingkan rtabel, dengan demikian butir pertanyaan pada instrumen penelitian ini dapat dikatakan valid.

Hasil Uji Reliabilitas yang diperoleh di dalam penelitian ini adalah sebagai berikut:

\section{Tabel 2.}

Hasil Uji Reliabilitas

\begin{tabular}{|c|c|}
\hline Cronbach's Alpha & N of Items \\
\hline .755 & 24 \\
\hline
\end{tabular}

Sumber: Data Olahan SPSS Versi 22.0

Berdasarkan tabel di atas dalat dilihat bahwa seluruh variabel memiliki cronbach's alpha $>0,60$. Sehingga variabel $\mathrm{X} 1, \mathrm{X} 2$ dan Y dapat dikatakan handal atau reliabel dan dapat digunakan sebagai alat ukur untuk penelitian selanjutnya.

Hasil Uji Normalitas yang diperoleh di dalam penelitian ini adalah sebagai berikut:
Tabel 3.

Hasil Uji Normalitas

\begin{tabular}{|c|c|c|c|c|c|c|c|}
\hline & \multicolumn{7}{|c|}{ Cases } \\
\hline & \multicolumn{2}{|c|}{ Valid } & \multicolumn{2}{|c|}{ Missing } & \multicolumn{3}{|c|}{ Total } \\
\hline & $\mathrm{N}$ & Percent & $\mathrm{N}$ & Percent & $\mathrm{N}$ & & ercent \\
\hline $\begin{array}{l}\text { Unstandardized } \\
\text { Residual }\end{array}$ & 100 & $100.0 \%$ & 0 & $0.0 \%$ & 1 & & $00.0 \%$ \\
\hline \multicolumn{8}{|c|}{ Tests of Normality } \\
\hline & \multicolumn{3}{|c|}{ Kolmogorov-Smirnov } & \multicolumn{4}{|c|}{ Shapiro-Wilk } \\
\hline & Statistic & df & Sig. & Statis & & df & Sig. \\
\hline $\begin{array}{l}\text { Unstandardized } \\
\text { Residual }\end{array}$ & .069 & 100 & $200^{\circ}$ & & 990 & 100 & .675 \\
\hline
\end{tabular}

Sumber: Data Olahan SPSS Versi 22.0

Dari output di atas dapat diketahui bahwa nilai signifikansi (Sig) pada Kolmogorov-Smirnov sebesar 0.200 . Karena signifikansi lebih dari 0.05 maka residual terdistribusi dengan normal.

Hasil uji Multikolinieritas yang diperoleh di dalam penelitian ini adalah sebagai berikut:

Tabel 4.

Hasil Uji Multikolinieritas

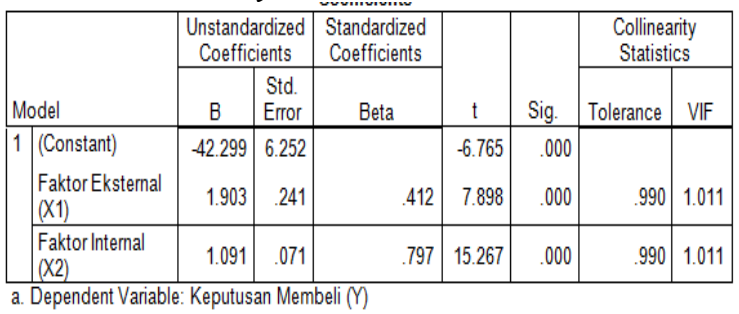

Sumber: Data Olahan, SPSS 22.0

Dari output di atas dapat diketahui bahwa nilai VIF kurang dari 10 dan nilai Tolerance lebih dari 0,1 untuk kedua variabel. Maka dapat disimpulkan bahwa model regresi tidak terjadi masalah multikolinieritas.

Hasil uji Heteroskedastisitas yang diperoleh di dalam penelitian ini adalah sebagai berikut:

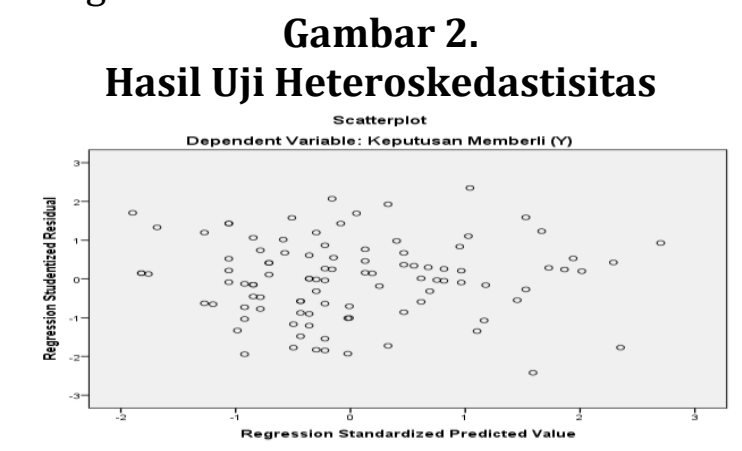

Sumber: Data Olahan SPSS Versi 22.0 
Dari grafik Scatterplot pada gambar Scatterplot Dependent Variabel peningkatan perekonomian terlihat titiktitik menyebar membentuk pola tidak beraturan di bawah dan di atas angka 0 (nol) pada sumbu Y. Hal ini memberi kesimpulan bahwa model regresi yang digunakan peneliti tidak ada gejala heteroskedastisitas dan layak untuk persamaan regresi.

Hasil Persamaan Analisis Regresi Linier Berganda yang diperoleh di dalam penelitian ini adalah sebagai berikut:

\section{Tabel 5.}

Hasil Regresi Linier Berganda

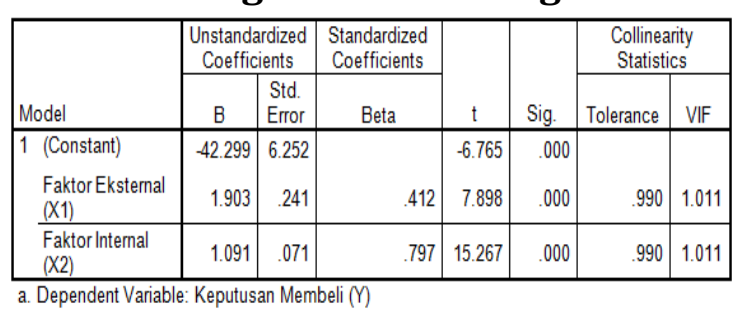

Sumber: Data Olahan SPSS Versi 22.0

Diperoleh persamaan regresi $\mathrm{Y}=$ $42.299+1.903 X 1+1.091 X 2$. Persamaan tersebut sesuai dengan rumus regresi linier berganda yaitu $\mathrm{Y}=\mathrm{a}+\mathrm{b} 1 \mathrm{X} 1+\mathrm{b} 2 \mathrm{X} 2$, di mana $Y$ merupakan lambang dari variabel terikat, a konstanta, b koefisien regresi untuk variabel bebas (X). Di mana konstanta (a) = -42.299, artinyajika faktor eksternal dan faktor internal diasumsikan tidak ada (0) maka keputusan membeli nilainya sebesar -42.299. Koefesien regresi (b) variabel faktor eksternal sebesar 1.903, artinya jika faktor eksternal mengalami kenaikan satu satuan, maka keputusan membeli akan mengalami kenaikan sebesar 1.903 satuan. Koefisien bernilai positif artinya hubungan antara faktor eksternal dan keputusan membeli adalah positif, artinya semakin tinggi nilai dari faktor eksternal maka semakin tinggi keputusan konsumen dalam membeli. Koefesien regresi (b) variabel faktor internal sebesar 1.091, artinya jika faktor internal mengalami kenaikan satu satuan, maka keputusan membeli akan mengalami kenaikan sebesar 1.091 satuan. Koefisien bernilai positif artinya hubungan antara faktor internal dan keputusan membeli adalah positif, artinya semakin tinggi nilai dari faktor internal maka semakin tinggi keputusan konsumen dalam membeli.

Dilihat dari hasil analisis yang diperoleh dari t hitung sebesar (7.898 > 1.984) dan untuk variabel faktor internal diperoleh nilai t hitung > t tabel (15.267 > 1.984) maka disimpulkan bahwa Ho (hipotesis nol) ditolak dan Ha (hipotesis alternative) diterima. Dan variabel bebas yang paling dominan mempengaruhi keputusan membeli konsumen adalah variabel X2 yaitu Faktor Internal.

Hasil uji simultan (uji- F) yang diperoleh di dalam penelitian ini adalah sebagai berikut:

\section{Hasil Uji Simultan (Uji-F)}

\begin{tabular}{|l|r|r|r|c|c|}
\hline Model & Sum of Squares & df & Mean Square & F & Sig. \\
\hline 1 Regression & 423.285 & 2 & 211.642 & 136.839 & $.000^{b}$ \\
Residual & 150.025 & 97 & 1.547 & & \\
Total & 573.310 & 99 & & & \\
\hline
\end{tabular}

a. Dependent Variable: Keputusan Membeli $(M)$

b. Predictors: (Constant), Faktor Internal (X2), Faktor Eksternal (X1)

Sumber: Data Olahan, SPSS 22.0

Dari tabel di atas menunjukkan bahwa Fhitung sebesar 136.839, sedangkan Ftabel pada taraf signifikan = 5\% dengan df1 (jumlah variabel bebas) ada 2 dan df2 (jumlah sampel) ada 100 maka (n-k-1=100-2-1) sama dengan 97, maka Ftabel diperoleh sebesar 3.090. Dilihat dari hasil output di atas disimpulkan hasil $\mathrm{F}$ hitung $>\mathrm{F}$ tabel (136.839 > 3.090) maka Ho ditolak, artinya bahwa faktor eksternal dan faktor internal secara bersama-sama berpengaruh terhadap keputusan membeli. 
Hasil koefisien determinasi yang diperoleh di dalam penelitian ini adalah sebagai berikut:

\section{Tabel 7.}

Hasil Uji Koefisien Determinasi

\begin{tabular}{|c|c|c|c|c|}
\hline Model & $R$ & RSquare & $\begin{array}{c}\text { Adjusted R } \\
\text { Square } \\
\end{array}$ & $\begin{array}{l}\text { Std. Error of the } \\
\text { Estimate }\end{array}$ \\
\hline 1 & $.859^{3}$ & .738 & .733 & 1.244 \\
\hline
\end{tabular}

Sumber: Data Olahan, SPSS 22.0

Berdasarkan tabel di atas, diperoleh nilai R2 (Adjusted R Square) sebesar 0,733 atau 73,3\%. Hal ini menunjukkan bahwa variabel sumbangan pengaruh variabel faktor eksternal dan faktor internal terhadap variabel keputusan membeli sebesar 73,3\%. Dan sisanya dipengaruhi oleh variabel atau faktor lain yang tidak dimasukkan dalam model penelitian ini.

Berdasarkan hasil output SPSS di atas dapat disimpulkan bahwa faktor eksternal dan faktor internal berpengaruh positif dan signifikan terhadap keputusan konsumen membeli makanan di restoran halal Kota Pekanbaru.

\section{SIMPULAN}

Berdasarkan hasil analisis data dan pembahasan penelitian, ditarik kesimpulan yaitu:

1. Dengan signifikansi level sebesar $5 \%$ dapat disimpulkan bahwa faktor eksternal dan faktor internal berpengaruh positif terhadap keputusan membeli. Berdasarkan hasil analisis data persamaan regresi linier berganda untuk pengaruh faktor eksternal dan faktor internal terhadap keputusan membeli adalah $\mathrm{Y}=-42.299+$ 1.903X1 + 1.091X2. Faktor eksternal dengan skor rata-rata 80.9 masuk dalam kategori "baik" dan berpengaruh terhadap keputusan membeli berdasarkan thitung (7.898) > ttabel (1.984) dengan uji dua pihak dan derajat bebas $(\mathrm{df})=98 ; \mathrm{a}=0,05$. Faktor internal dengan skor rata-rata 82.3 masuk dalam kategori "baik" dan berpengaruh terhadap keputusan membeli berdasarkan thitung (15.267) > ttabel (1.984). Maka disimpulkan bahwa Ho ditolak, artinya faktor eksternal dan faktor internal berpengaruh terhadap keputusan membeli. Nilai t hitung positif, artinya berpengaruh positif, artinya semakin tinggi faktor eksternal dan faktor internal maka semakin tinggi pula keputusan membeli konsumen. Sedangkan secara simultan faktor eksternal dan faktor internal secara bersamasama berpengaruh terhadap keputusan membeli karena nilai Fhitung (136.839) > Ftabel (3.090). Berdasarkan berdasarkan nilai r2 (adjusted $r$ square) variabel faktor eksternal dan faktor internal memberikan kontribusi sebesar 0,733 atau $73,3 \%$. Hal ini menunjukkan bahwa variabel sumbangan pengaruh variabel faktor eksternal dan faktor internal terhadap variabel keputusan membeli sebesar 73,3\%. Dan sisanya dipengaruhi oleh variabel atau faktor lain yang tidak dimasukkan dalam model penelitian ini.

2. Berdasarkan hasil pengujian SPPS Version 22 menunjukkan bahwa faktor eksternal memiliki nilai $t$ hitung yang lebih besar dari $t$ tabel (1.984) yaitu sebesar 7.898 dan faktor internal memiliki nilai $t$ hitung sebesar 15.267. Maka disimpulkan bahwa faktor yang paling dominan mempengaruhi 
keputusan membeli konsumen adalah faktor internal (X2) sebesar 15.267.

\section{SARAN}

Berdasarkan pembahasan dari hasil penelitian yang telah dijabarkan di atas, penulis memberikan beberapa saran antara lain:

1. Kepada Pemerintah khususnya Dinas/Instansi/Lembaga terkait untuk melakukan tindak tegas kepada UMKM khususnya restoran atau rumah makan yang belum memiliki sertifikat halal untuk segera mensertifikasi produknya. Ini disebabkan masih rendahnya kesadaran produsen dalam mengajukan sertifikasi halal.

2. Lembaga jaminan halal terkait harus melakukan sosialisasi atau edukasi baik kepada para pelaku usaha maupun masyarakat terhadap pentingnya sertifikasi halal pada produk khususnya produk pangan, obat-obatan, makanan dan kosmetik.

3. Kepada para pelaku bisnis untuk lebih mengutamakan konsumen yang diwujudkan dalam bentuk sertifikasi halal pada produk olahannya sehingga terjamin kehalalan makanan yang akan dikonsumsi oleh konsumen.

4. Kepada konsumen untuk dapat menjadikan halal, haram dan syubhat sebagai panduan dalam memilih makanan.

5. Bagi penelitian selanjutnya diharapkan dapat manambahkan faktor-faktor lain yang mempengaruhi keputusan pembelian. Dengan demikian akan memberikan kontribusi yang baik untuk penelitian selanjutnya tentang keputusan pembelian.

\section{DAFTAR RUJUKAN}

Ali, Muchtar. (2016). Konsep Makanan Halal Dalam Tinjauan Syariah dan Tanggung Jawab Produk Atas Produsen Industri Halal. Jurnal Ahkam: XVI, (2).

Cooper, Donald R. (1996). Metodologi Penelitian Bisnis Jilid I Edisi Kelima. Jakarta: Erlangga.

LPPOM MUI. (2015). Jurnal Halal Edisi Lengkap. Penerbit Lembaga Pengkajian Pangan Obat-obatan dan Kosmetika Majelis Ulama Indonesia. Jakarta: LPPOM MUI.

Mangkunegara, Anwar Prabu. (2005). Perilaku Konsumen Edisi Revisi. Bandung: PT Refika Aditama.

Pejabat Pengelola Informasi dan Dokumentasi. Data Rumah Makan dan Restoran Kota Pekanbaru oleh Dinas Penanaman Modal dan Pelayanan Terpadu Satu Pintu, Dokumen Nomor 300029192, publikasi tanggal 02 April 2019.

Peraturan Daerah Kota Pekanbaru Nomor 6 Tahun 2011 Tentang Pajak Restoran.

Rakhmat, Jalaluddin. (2012). Psikologi Komunikasi. Bandung: Penerbit PT Remaja Rosdakarya.

Sekaran, Uma. (2006). Metodologi Penelitian untuk Bisnis. Jakarta: Salemba Empat.

Setiadi, Nugroho J. (2010). Perilaku Konsumen. Edisi Revisi. Jakarta: Penerbit Kencana.

-----.-. (2003). Perilaku Konsumen Dalam Konsep Dan Implikasi Untuk Strategi Penelitian Pemasaran. Jakarta: Penerbit Kencana. . (2008). Perilaku Konsumen Dalam Konsep Dan Implikasi Untuk Strategi Penelitian Pemasaran. Jakarta: Penerbit Kencana.

-----------. (2013). Perilaku Konsumen Dalam Konsep Dan Implikasi Untuk 
Strategi Penelitian Pemasaran. Jakarta: Penerbit Kencana.

Sofjan, Assauri. (2004). Manajemen Pemasaran. Jakarta: PT. Raja Grafindo Persada.

Suharno. (2010). Marketing in Practice Edisi Pertama. Yogyakarta: Graha Ilmu.

Sunyoto, Danang. (2012). Konsep Dasar Riset Pemasaran dan Perilaku Konsumen. Yogyakarta: PT. Buku Seru.

Suryani, Tatik. (2008). Perilaku Konsumen, Implikasi Pada Strategi Pemasaran. Yogyakarta: Graha Ilmu. 